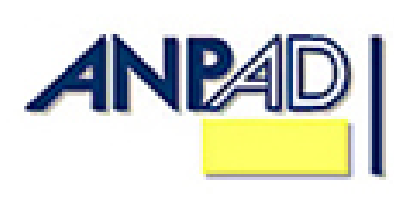

Available online at http://www.anpad.org.br/bar

BAR, Curitiba, v. 8, n. 3, art. 1, pp. 225-246, July/Sept. 2011

\title{
Perceptions of Justice after Recovery Efforts in Internet Purchasing: the Impact on Consumer Trust and Loyalty toward Retailing Sites and Online Shopping in General
}

\author{
Cristiane Pizzutti dos Santos * \\ E-mail address: crispizzutti@gmail.com \\ Universidade Federal do Rio Grande do Sul - UFRGS \\ Porto Alegre, RS, Brazil. \\ Daniel Von der Heyde Fernandes \\ E-mail address: dfernandes@rsm.nl \\ Erasmus University \\ Rotterdam, Netherlands.
}

* Corresponding author: Cristiane Pizzutti dos Santos Rua Washington Luis, 855, Porto Alegre, RS, 90010-460, Brazil.

Copyright (C) 2011 Brazilian Administration Review. All rights reserved, including rights for translation. Parts of this work may be quoted without prior knowledge on the condition that the source is identified. 


\begin{abstract}
The main goal of this paper is to extend the traditional theoretical model of service recovery to the online purchasing environment by investigating the impact of perceptions of justice after recovery efforts toward unsatisfactory Internet purchasing on customer trust and loyalty. The authors develop a theoretical model focusing on interrelationships among complaint handling evaluations, quality of prior experience, familiarity, trust, perceived value and loyalty. To test this model, 3,339 customers from all over Brazil who had been engaged in complaint processes about online purchases within the past 6 months answered an online questionnaire. Findings indicate that interpersonal treatment by the e-retailer improves consumer perceptions of the online recovery process. Consumer trust in the firm's website is strongly influenced by satisfaction with complaint handling, familiarity and the quality of prior experiences with the website, while consumer trust in Internet shopping is mainly affected by familiarity and the quality of prior experiences with Internet purchasing. These two dimensions of trust are distinct and represent discrete facets, as they do not impact each other. Moreover, repurchase intentions and word-of-mouth communication are influenced by consumer trust.
\end{abstract}

Key words: recovery efforts; consumer trust; loyalty; internet purchasing. 


\section{Introduction}

The prominent growth of electronic retailing has been accompanied by the diagnosis of recurrent failures, some of which are new (when compared to the offline context) (Forbes, Kelley, \& Hoffman, 2005). One source reports that for every four purchases made through the Internet, at least one results in some kind of dissatisfaction (Zemke \& Connellan, 2001). Exacerbating this situation, electronic retailing seems to be an almost perfect market, as the information is instantaneous and consumers can compare offers from all over the world. Therefore, with the competition just one mouse click away, the exodus of customers becomes much easier (Shankar, Smith, \& Rangaswamy, 2003). Within this context, recovery efforts become essential for retaining customers and consequently for the survival of the firm in the business context.

A consistent theoretical framework sustained by empirical evidence suggests that satisfactory complaint handling contributes to customer retention, loyalty and commitment (Smith \& Bolton, 1998; Tax, Brown, \& Chandrashekaran, 1998; Weun, Beauty, \& Jones, 2004). On the other hand, failure to address customer dissatisfaction represents a double failure and could lead to reduced trust, loss of customers and negative word-of-mouth, which has a stronger impact than positive word-of-mouth (Berry \& Parasuraman, 1991). However, most research carried out on this topic has centered on the more traditional 'bricks and mortar' offline retail environment.

It is generally accepted that the Internet does not change the fundamental principles of marketing (Berry \& Parasuraman, 1991; Holloway \& Beatty, 2003), and accordingly, the understanding we have achieved from offline service recovery studies is highly relevant online. However, there is a number of issues that might be considered unique to the Internet environment.

Firstly, the interaction, mainly face-to-face, that is so central in failures and recovery processes in traditional retailing, in the online environment, is largely substituted by technology. Another factor that appears to differentiate recovery online is the fact that, while in an offline business transaction a consumer interacts with the seller, and sellers can detect failures and quickly take measures for recovery. In an online transaction, a consumer interacts with a mediating environment that may not detect failures. For this reason, consumers should be given a means of voicing their concerns easily (Ahmad, 2002). Third, when a consumer considers purchasing online he/she may have different levels of trust concerning individual perceptions of the online environment as a whole - what McKnight, Choudhury and Kacmar (2002) called institution based trust -, and his/her perceptions of a specific web-vendor - called trusting beliefs by McKnight et al. (2002). These two dimensions of trust are not present in the offline context, and few empirical studies have simultaneously explored both systembased and company specific trust and the impact of both on repurchase intentions, not to mention the interaction of these two factors within the e-commerce arena.

A small number of studies contribute to knowledge about recovery perceptions in electronic purchasing. Descriptive studies have sought to identify and classify failures that occur in electronic retailing, the recovery strategies most commonly used and the consequences of such strategies (Ahmad, 2002; Forbes et al., 2005; Holloway \& Beatty, 2003; Nasir, 2004). Coming closer to what has been developed in the offline environment, Holloway, Wang and Parish (2005) sought to empirically investigate the moderating influence of the cumulative online purchasing experience by testing a traditional complaint handling framework within the context of online retailing, using distributive justice, experience, satisfaction with complaint handling, repurchase intention and wordof-mouth communication. On the other hand, other important variables have been neglected (e.g., other dimensions of justice, perceived value and familiarity), some of them unique to the Internet context, such as trust in the Internet and trust in the site and familiarity.

Based on this scenario, the present study aims to extend the traditional theoretical model of service failure and recovery to the online purchasing environment, investigating the impact of perceptions of justice after recovery efforts towards an online purchasing on customer trust and loyalty. In order to do this, a theoretical model will be constructed and tested, in which inter-relations 
among the specific aspects of the complaint handling evaluations will be analyzed together with the aforementioned constructs perceived value, prior experience, familiarity, trust and loyalty. Moreover, we explore these impacts in two different contexts: the Internet as a whole and retailing sites. We believe they may influence each other, e.g., an inadequate failure resolution from a web vendor can influence not only the consumer's trust in this virtual vendor in particular but also on online retailing in general and vice-versa.

This article consists of three main parts. The first deals with the theoretical foundation underpinning the study, and the framework. The second discusses the aspects related to the research method, and the third presents the results.

\section{Theoretical Foundation and Research Hypotheses}

\section{Justice perceptions and satisfaction with complaint handling}

A complaint handling process begins with a complaint made by a customer which, typically, produces (a) interaction between the claimant and representatives of the company and (b) outcomes (Tax et al., 1998). Contemporary studies on complaint management have offered substantial evidence on the suitability of the concept of fairness and its three dimensions - procedural, distributive and interactional - as a base for understanding the process of complaining and its outcomes (Blodgett, Hill, \& Tax, 1997; Goodwin \& Ross, 1992; Santos \& Rossi, 2002; Smith, Bolton, \& Wagner, 1999; Tax et al., 1998).

Distributive Justice refers to the allocation of benefits and costs between the parties to a transaction. Within the context of the complaint, distributions are seen as a tangible outcome offered to the claimant by the firm (e.g., exchanging the product or reimbursing the money). The second dimension, Procedural Justice, concerns policies and procedures used by firms, and has six subdimensions: flexibility, accessibility, process control, decision control, speed of response and acceptance of responsibility (Tax et al., 1998; Thibaut \& Walker, 1975). Interactional Justice is the third dimension and involves the manner in which the employees treat and communicate with the customer during the complaint. Six sub-dimensions have been studied: courtesy, honesty, empathy, effort, explanations and apologizing (Clemmer, 1988; Tax et al., 1998).

It is important to highlight that the latter - interactional justice - may appear of little significance in the case of online purchasing, due to the lack of physical interactions. However, though almost irrelevant at the time of purchase, this dimension of justice appears to become an important element for an efficient recovery, due to the consumer's need, either through e-mail or over the telephone, to feel well treated by the company. Hence, even though there is no face-to-face contact between the customer and the company representative, personal treatment during the recovery will help to create a general assessment of the degree to which the company was fair.

Post-purchase satisfaction has been considered a central mediator that links prior beliefs to postpurchase cognitive structures, communication and repurchase behavior (Westbrook, 1987). Similarly, satisfaction with the handling of a complaint can be considered a central element mediating the relationship between assessments made regarding these management and post-complaint attitudes and behavior. According to the literature on social justice, satisfaction is linked to assessments of fairness in various conflict situations (Messick \& Cook, 1983). Extending this logic to complaint handling, it is widely recognized that consumer satisfaction with the complaint episode results from the assessment of aspects regarding the final outcome (distributive justice), the process that led to the outcome (procedural justice) and the manner in which the consumer was treated and informed during the episode (interactional justice), that is, how fair these aspects were (Blodgett et al., 1997; Goodwin \& Ross, 1992; Liao, 2007; Mattila \& Patterson, 2004; Smith et al., 1999; Tax et al., 1998). Therefore, this study presents the following group of hypotheses: 
H1: Perceptions of procedural justice will have a positive impact on satisfaction with complaint handling in online purchasing.

H2: Perceptions of interactional justice will have a positive impact on satisfaction with complaint handling in online purchasing.

H3: Perceptions of distributive justice will have a positive impact on satisfaction with complaint handling in online purchasing.

\section{Satisfaction with complaint handling in online purchasing and consumer trust}

The construct of trust has been widely studied in the literature on electronic commerce. It has been seen as fundamental in explaining consumer repurchase behavior on the Internet (Pavlou, 2003; Sultan, Urban, Shankar, \& Bart, 2002), as well as outside it (Garbarino \& Johnson, 1999; Morgan \& Hunt, 1994; Nooteboom, Berger, \& Noorderhaven, 1997). Trust is a concept studied in several disciplines, and, as a result, there are different definitions. In this study, consumer trust in an online retailer is defined as "the willingness of the consumer to be vulnerable to actions of the electronic retailer during an Internet transaction based on the expectation that the retailer will behave in a suitable manner, independently of the ability of the consumer to monitor or control that electronic retailer" (Mayer, Davis, \& Schoorman, 1995, p. 79).

According to the literature, consumer trust in an Internet purchase will have two dimensions: trust in the purchase site and in the Internet as a whole (Chen \& Dhillon, 1993). These facets are, then, distinct nodes regarding which the customer makes independent judgments during the course of the exchange. This idea is corroborated by Grabner-Krauter and Kalusha (2003), who dealt with two dimensions of trust in the online environment: trust based on the system (system-based trust), that would be trust in the Internet as a means of purchase and trust in the particular retailer (e-tailer trust). According to the same authors, while the latter has been widely studied, the former has been largely neglected.

In studies of traditional offline retail channels, consumer post-recovery satisfaction is clearly linked to future attitudes and behaviors (Bitner, Booms, \& Tetreault, 1990; Dube \& Maute, 1998; Tax et al., 1998; Webster \& Sundaram, 1998). However, prior work has focused more on the immediate intentions of behavior (repurchase intentions, for example) and less on the attitudinal variables (such as trust). In one exception, Tax, Brown and Chandrashekaran (1998) explored the relationship between post-complaint satisfaction and relational variables and found a significant and positive relationship between resolution satisfaction and post-complaint trust.

Similarly, e-commerce research has also linked consumer satisfaction to company trust (Pavlou, 2003; Ribbink, Van Riel, Liljander, \& Streukens, 2004). Therefore, when a customer perceives the complaint handling performance of a company as fair and satisfactory, his/her feelings of trust tend to strengthen. Conflict situations appear to be even more critical, as it is in adversity that partnerships are put to the test. Accordingly, a satisfactory solution of a failure in delivering a product, for example, can say more about the credibility of a certain site than a routine situation. Similarly, an efficient recovery process can help increase trust in electronic commerce as a whole. Ribbink, Van Riel, Liljander and Streukens (2004), in fact, state that satisfactory experiences with a specific electronic retailer inspire consumer trust in the virtual medium (system-based trust). Based on this information, we propose that:

H4: Consumer satisfaction with complaint handling in online purchasing will have a positive impact on the consumer's trust in the company's site (a) and in online retailing (b).

Jarvenpaa, Tractinsky and Vitale (2003) argue that the most significant long-term barrier to reaching the full potential of the Internet is the lack of consumer trust, both in the merchant's honesty and in the merchant's competence to fill Internet orders. Trust is a critical factor in any relationship in 
which the trustor (e.g., consumer) does not have direct control over the actions of a trustee (e.g., merchant or store), the decision is important and the environment is uncertain (Mayer et al., 1995).

Drawing from cognitive consistency arguments, consumer trust in Internet shopping is proposed to directly influence consumer trust in the firm's web site. When the salesperson is absent from or peripheral to the selling and buying process, as is generally the case with Internet stores (Lohse, Bellman, \& Johnson, 2000), then the primary target of the consumer's trust is the Internet as a whole (Grabner-Krauter \& Kaluska, 2003; Milne \& Boza, 1999). So, trust in Internet shopping may influence trust in a company's site because it offers a guarantee of the consistent and competent performance of the companies operating in the environment.

The literature also offers evidence for the existence of a corresponding relationship, that is, consumer trust in an online selling channel is likely to enhance one's system-based trust (GrabnerKrauter \& Kaluska, 2003; Lee \& Turban, 2001). According to the dispositional approach, consumers develop attitudes and action tendencies to respond to industry-context situations in a particular, predetermined manner (Nijssen, Singh, Sirdeshmukh, \& Holzmueller, 2003). These dispositions are thought to emerge as consumers synthesize their information and experiences across multiple exchanges (with different sellers) within an industry to develop higher-level inferences.

Although we do not explore which type of trust comes first, system-based trust or trust in an online selling channel, we propose that:

H5: Consumer trust in online retailing will have a reciprocal impact on consumer trust in the company's site.

\section{Quality of prior experiences, familiarity and consumer trust}

In an online environment, the quality of prior experiences with online purchasing plays an important role, as it links previous behavior with the probability of that behavior being repeated (Chiou, 2004). The consumer experience can be either direct, such as searching for information, purchase and consumption of products, or indirect, such as exposure to propaganda and observation of other consumers (Alba, Hutchinson, \& Wesley, 1987). The experience of consumption is not limited to a specific category of product, but is also related to diverse purchase situations, as well as the assessment of purchase alternatives (Suk \& Mitchell, 2004). Therefore, in the same way as trust operationalisation, cumulative consumer experience involves two dimensions: (a) specific experiences with the site and (b) experiences with purchasing online. The consumer's prior experience with the firm's site or with the online environment in general can be assessed positively with good, pleasant and valuable experiences, or negatively with bad, unpleasant, valueless experiences. Thus, by affecting the consumer's ability to make predictions based on benefits and value received, prior experiences are expected to positively impact consumer trust.

Drawing on attribution theory, we posit that positive prior experiences will lead the buyer to benefit the firm with benevolent attributions, thereby enhancing feelings of trust. On the other hand, negative prior experience generates suspicion and doubt about the website, reducing consumer trust in the site. In short, as trust is formed not as a result of a single episode but based on successive good experiences with the firm, it is expected that experiences prior to the complaint, in addition to the influence of satisfaction with the recovery process, significantly influence trust in the firm's site. Therefore, it is proposed that:

H6: Quality of Prior experience with the company's site will positively influence consumer trust in the site.

Regarding Internet shopping, it is also proposed that the quality of prior experience of the online retailing environment will impact consumer trust on the medium. When prior experiences with Internet purchasing are bad, consumers may develop uncertainty regarding the Web and vice-versa. Consumers tend to accumulate knowledge and strong beliefs about the system, which will increase 
their overall attitudes toward it (Yoh, Damhorst, Sapp, \& Laczniak, 2003). Based on this reasoning, we hypothesize that:

H7: Quality of Prior experience with online retailing will positively influence consumer trust in online retailing.

While prior experience has to do with the valence of the experience (good, pleasant, satisfactory or bad, unpleasant, dissatisfactory), familiarity is related to the knowledge acquired and stored in memory, and with the ability to make decisions (Alba et al., 1987; Bettman \& Park, 1980). Familiarity with the firm's website reflects the consumer's knowledge about purchasing from a specific online retailer. Consequently, it deals with knowing and understanding the trading partner, its work procedures, goals, beliefs and values. It builds trust by creating appropriate frameworks within which the trustor can place his/her beliefs about the trustee and know what to expect from it (Gefen, 2000).

Another way in which familiarity builds trust is that familiarity results in fewer communicational misunderstandings (Kumar, 1996) that could otherwise undermine trust. Yoon (2002) shows that website trust is influenced by consumer familiarity with and prior experience of ecommerce.

H8: Familiarity with the company's site will positively influence consumer trust in the site.

Familiarity could also be related to the Internet shopping experience in general and not only to a specific web site (Sultan et al., 2002). From this perspective, consumers will accumulate knowledge about purchasing on the Internet and, therefore, will become more skillful at purchasing. Familiarity with the Internet thus reflects the ability of the consumer to understand information based on the Internet (Moreau, Lehmann, \& Markman, 2001). An expert user, who is familiar with Internet purchasing, is more likely to have greater confidence in the Internet than a novice user (Sultan et al., 2002). Therefore, online trust may be higher for an Internet-savvy consumer. For this reason, we propose the following:

H9: Familiarity with online retailing will positively influence consumer trust in online retailing.

\section{Antecedents of loyalty}

In the words of Reichheld and Schefter (2000, p. 113): "loyalty is not won with technology, but through the consistent delivery of greater value to the customer". Loyalty is usually measured by two outcome dimensions: consumer repurchase intentions and positive WOM.

Conceptual (Nooteboom et al., 1997) and empirical (Agustin \& Singh, 2005; Morgan \& Hunt, 1994; Tax et al., 1998) studies emphasize trust as a fundamental ingredient for the development of long-lasting relationships between consumers and firms. In online commerce, trust appears to be even more relevant since there is a lack of the physical contact and the tangible aspects which are present in traditional retailing. Therefore, the success of the firm, as well as the future of e-commerce will depend on building trust and credibility among consumers and of a favorable attitude towards the web. This idea is reinforced by Reichheld and Schefter (2000), Pavlou (2003) and Ribbink et al. (2004), though the latter authors noted a continued lack of empirical evidence establishing a link between trust and loyalty in the online environment. Thus, it is proposed that:

H10: Consumer trust in the site will have a positive impact on the intention to repurchase from the site and (b) to spread positive WOM regarding the site.

H11: Consumer trust in online retailing will have a positive impact on the intention to repurchase from the Internet and (b) to spread positive WOM about online retailing.

In addition to the influence of trust on consumer loyalty, this study proposes the existence of a second precursor of consumer loyalty: the level of perceived value. Perceived value refers to the consumer's assessment of the benefits and costs of maintaining a relationship with a firm 
(Sirdeshmukh, Singh, \& Sabol, 2002). The logic here is that, even when the consumer extracts benefits originating from the relational exchange with the firm, if high maintenance costs are demanded, the relationship will be less attractive and there will be less evidence of loyalty. The findings from Sirdeshmukh, Singh and Sabol (2002) offer empirical evidence of this reasoning. In this study, perceived value emerged as a significant antecedent of consumer loyalty, independent of the service category. In the online context, Broekhuizen (2006) found the effect of items linked to perceived value (time and effort expended) in repurchase intentions. Harris and Goode (2004) corroborated the strong effect of value on loyalty. Based on this reasoning, the following hypotheses can be stated:

H12: The perceived value of the site will have a positive impact on the intention to repurchase from the site and (b) to spread positive WOM regarding the site.

Based on the literature and established hypotheses, Figure 1 presents the theoretical model to be investigated.

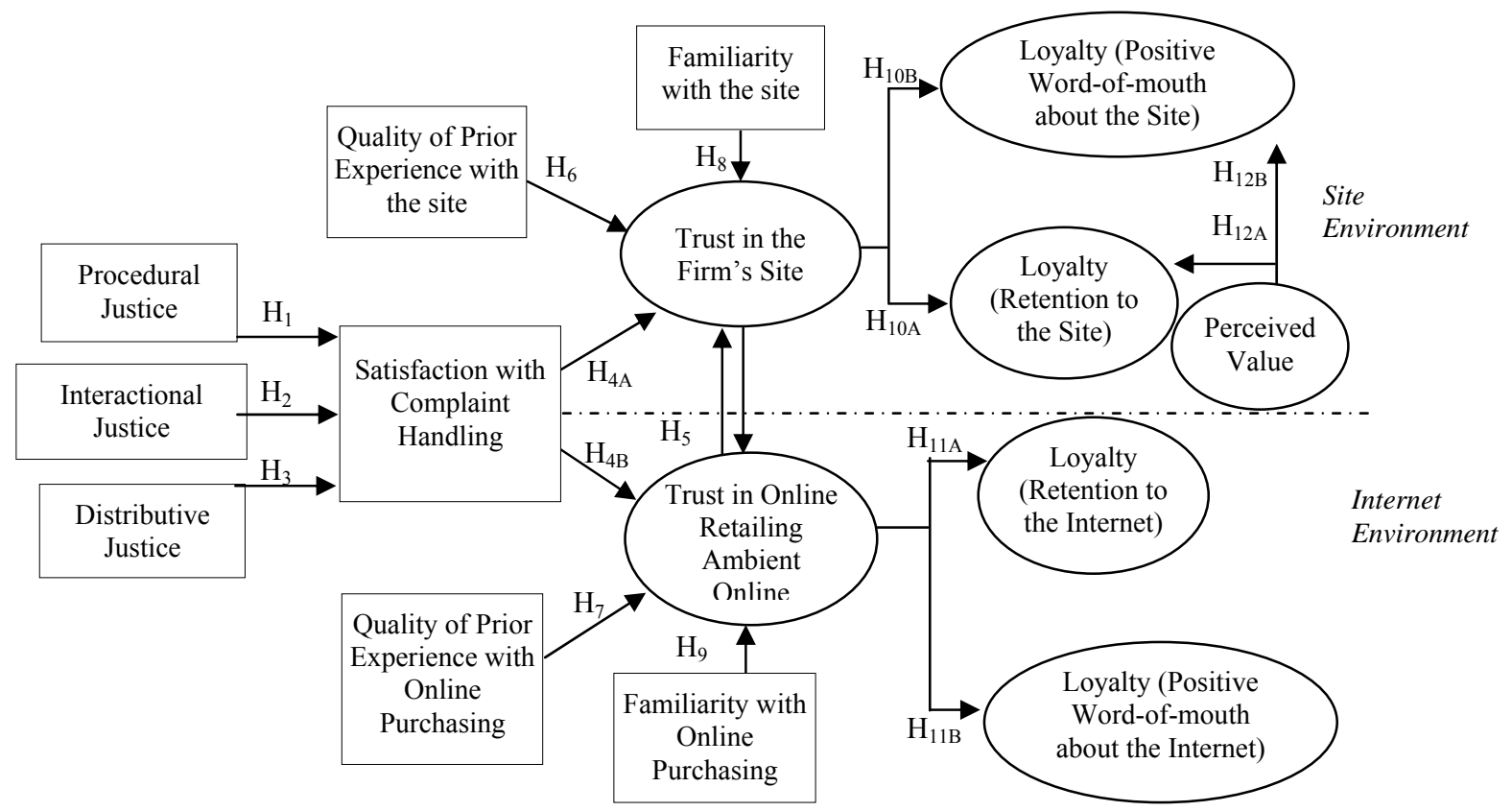

Figure 1. Framework for Understanding the Impact of Perceptions of Justice after Recovery Efforts on Consumer Trust and Loyalty in the Internet Purchasing Context.

\section{Method}

We administered a cross-sectional survey using an online questionnaire with customers representing every state in Brazil. This survey was accomplished in partnership with E-BIT (http://www.ebit.com.br), a Brazilian company specializing in Internet purchasing research. E-BIT has databases from a number of e-tailers, including two of Brazil's largest companies: Submarino and Americanas.com. E-BIT's database retains data for consumers who have made an online purchase within the previous 6 months. From this data, only those consumers who had experienced a failure and had complained to the online selling channel were asked to answer the survey. We had an initial data set of 3,339 respondents. We collected this data in November 2006, and in exchange for their involvement, the participants received 7,000 bits, which could be used to compete for prizes on the EBIT site.

The initial portion of the survey instrument contained questions that required subjects to report the details of a recent online purchase with a dissatisfactory experience that led to their lodging a complaint. Details included a description of what caused the complaint, the media used to lodge the 
complaint and the time of the year the complaint was made. These questions provided useful information that contributed towards understanding complaint handling evaluations and helped the respondent focus on the encounter.

Following these initial open- and closed-ended questions, scaled measures adapted from previous studies on service recovery literature were applied. The measures of interactional (6 items), procedural (6 items), distributive justice (4 items) and satisfaction with complaint handling (3 items) were taken from Tax et al. (1998); perceived value (4 items), consumer trust ( 8 items; 4 related to trust in the site of the company and 4 related to trust in the online environment) were adapted from Sirdeshmukh et al. (2002); repurchase intention (4 items) and positive word-of-mouth (3 items) were adapted from Oliver and Swan (1989) and Zeithaml, Berry and Parasuraman (1996). All of them are five point Likert scales.

Measures were translated into Portuguese using the back-translation technique and submitted to face validity - two marketing professors identified problems related to the scale questions. The questionnaire was modified when requested and a pre-test with 15 people was carried out. The scale items used can be seen in the Appendix.

Given our central objective - to test the elaborated hypotheses and examine the statistic significance of the proposed model - the Structural Equation Modeling (SEM) was utilized. Following Byrne's recommendation (1994), the estimation method chosen was the ERLS (iteratively reweighted generalized least squares), available in EQS software, which is not based on the prerogative of normality. In addition, as the chi-square test is very sensitive to normality deviations and samples above 200, the analysis was carried out with other goodness of fit indices besides this test.

\section{Results}

The results obtained in the survey are presented in the following way: first, a general profile of the sample is presented and the measurement model is examined using Confirmatory Factor Analysis (CFA). After the establishment of the validity and reliability of the measures used, the examination of the structural model is performed.

Data were examined to ensure that it abided by the multivariate assumptions of normality (tested through Mardia's coefficient), homoscedasticity (through Box's M test) and linearity (through bivariate scatterplots). Furthermore, we sought to remove cases labeled as outliers identified by the Mahalanobis distance. Following these examinations, the sample consisted of 3,206. The response rate was $16.5 \%$, which can be considered high, considering that only those who had experienced a problem with a completed online purchase could respond to the survey and participation was spontaneous.

\section{Sample profile}

The sample consisted of individual consumers residing in different areas of Brazil. All 27 Brazilian states are represented in the sample, as it reflects a broader range of demographic and socioeconomic characteristics among online Brazilian shoppers. Ages ranged from 18 to 75 , with $39.4 \%$ between the ages of 25 and 35 . More than half (60.7\%) were male. Educationally, $81.8 \%$ of the respondents had a high school degree. Regarding monthly household income, $38 \%$ were at or above US\$ 2,000. Most complaints were made only by email (40.7\%), $16.9 \%$ by phone and $36.7 \%$ were made by both phone and email. The highest frequency of complaints had been made over the previous 3 months $(57.6 \%)$. This shows that a large part of the complaint episodes was reasonably recent, increasing the likelihood of obtaining reliable answers.

Overall, the respondents were experienced online shoppers (mean score of 4.26 for Familiarity with Internet Purchases on a Likert scale of 5), reported favorable views of their prior online 
experiences (mean score of 4.28) and reported moderately high trust in online retailing as a whole (3.79). With regard to the online selling channel specified in their complaint, respondents reported less familiarity (3.55), less satisfaction with their prior experiences (3.81) and neutral feelings of trust (3.11). Perceptions of fairness dimensions were generally clustered in the neutral mid-point of the Likert scale (Interactional $=2.93$, Procedural $=2.95$, Distributive $=3.03$ ). The likelihood of offering positive WOM and repurchase intentions was on the low side (2.82 and 2.89 , respectively), especially as compared with the likelihood of positive WOM for e-commerce in general (4.36) and the continued likelihood of future online purchasing (4.43). These findings are presented in the Appendix.

\section{Validity and reliability}

For the measurement model, in line with the work of Anderson and Gerbing (1988), all observed variables were forced to load on their respective latent variables and were not allowed to cross-load. Several fit indices were evaluated to assess the fit of the measurement model to the data. Each index was adopted based on recommendations from the psychometric literature that supported their consistency and ability to assess unique aspects of model fit. When these indices are used in conjunction to evaluate model fit, values that approach .90 for the CFI, the NFI and the NNFI, and values less than or equal to .08 for the RMSEA are indicative of a good fit of the model to the data (Hair, Anderson, Tatham, \& Black, 1998).

Results of the confirmatory factor analysis indicate that the measurement model fit the data well $\left(\chi^{2}=18974.54, \mathrm{df}=1297 ; \mathrm{CFI}=.96 ; \mathrm{NFI}\right.$ and NNFI $\left.=.95 ; \mathrm{RMSEA}=.06\right)$. The chi-square statistic was significant $(\mathrm{p}<.001)$, but this was expected because the chi-square statistic is sensitive to large sample sizes ( $\mathrm{n}>200$; Hair et al., 1998). All measures included in the analysis were reliable, with construct reliability estimates that ranged from .73 to .90 . In addition, convergent validity was supported as all items loaded strongly and significantly on their respective factors, and the average variance extracted (AVE) for each latent variable exceeded .50 (Fornell \& Larcker, 1981). The correlations among all constructs are all below the .90 threshold, suggesting that all constructs are distinct from each other. Furthermore, the average variance extracted for each latent factor exceeded the respective squared correlation between factors, providing evidence of discriminant validity (Fornell \& Larcker, 1981). Means, Standard Deviations, Standardized loadings, composite reliabilities and Cronbach's alpha coefficients are provided in the Appendix.

Finally, we confirm discriminant validity by comparing nested models for each pair of latent constructs in which we either allow the correlation between two constructs to be free or restrict the correlation to 1 . Collectively, these models represent 68 individual tests of discriminant validity. Discriminant validity is supported; the $\chi^{2}$ statistic is significantly lower $(\mathrm{p}<.05)$ in the unconstrained model than in the constrained model for almost all constructs. Of the 51 tests, only 1 suggested that two of our constructs were not distinct; namely the facets of loyalty toward the website (Word-ofmouth and Retention). These facets were then considered to be dimensions of a higher order factor (i.e., loyalty). On the basis of these tests, we concluded that our measures are valid and measure fifteen distinct constructs.

\section{Examination of the hypotheses}

After the examination of the measures used, this study focused on the theoretical structure. The investigation of the set of hypotheses will be made primarily through the goodness-of-fit indices of the hybrid model and the significance and magnitude of estimated regression coefficients. Moreover, a determination coefficient was established for each structural equation, which represents the proportion of variance of the dependent variable explained by the independent variables.

The findings obtained with the analysis of the structural model with a base of 3206 customers are shown in Table 1. The chi-square value is significant and the normed chi-square (chisquare/degrees of freedom) of 18.54 is higher than the threshold suggested by the literature. However, knowing that this test is very sensitive to normality deviations and to samples higher than 200, the 
analysis of the chi-square value must be conducted along with other adjustment criteria (Hair et al., 1998). Goodness-of-fit indexes CFI, NFI, NNFI, all over 0.90, are satisfactory and the RMSEA of 0.06 are acceptable.

The effects of perceptions of justice (interactional, distributive and procedural) on satisfaction with the complaint handling, established in hypotheses $\mathrm{H}_{1}, \mathrm{H}_{2}$ e $\mathrm{H}_{3}$, respectively, were supported by the results. The $\mathrm{R}^{2}$ of 0.85 indicates that the three aspects of justice (personal treatment, resolution process and tangible results) explained a significant proportion (85\%) of variance in the consumer's satisfaction with complaint handling. The evaluations of processes during the complaint management had little influence on satisfaction (regression coefficient of 0.25 ). The tangible results (distributive justice) obtained through complaint had a higher effect on satisfaction (0.70) than interactional aspects (0.54), which corroborates the importance of offering compensation to the customer rather then merely treating him/her well.

The results also support hypothesis $\mathrm{H}_{4}$, in which the relationship between satisfaction with complaint handling and consumer trust is established. However, the impact of satisfaction on consumer trust in the firm's web site is much higher (0.65) than on online purchasing as a whole (0.14). This is consistent with the idea that, in conflict situations, specific perceptions of the episode may affect (enhancing or depleting) trust in relation to the other party involved in the dispute, but this effect is not extended to other online retailers. It is important to stress that the impact of satisfaction on consumer trust in the web site is much higher than the effect of familiarity $(0.35)$, prior experience with the site (0.15) and consumer trust in online purchasing (0.06). When consumers perceive that the company acted appropriately in the resolution of their problem, they update their impressions about the quality of the company and, thus, their feelings of trust are reinforced. The opposite occurs when consumers perceive that the company handled their complaint negligently and/or ineffectively. The $\mathrm{R}^{2}$ of 0.61 reflects the good explanatory power of consumer trust in the firm's web site.

Table 1

Estimated Regression Coefficients for the Theoretical Relationships Established

\begin{tabular}{lccc}
\hline Model Relationships & $\begin{array}{c}\text { Standardized Regression } \\
\text { Coefficient }\end{array}$ & Hypotheses & Findings \\
\hline Dependent Variable: Satisfaction with Complaint Handling & $\mathbf{0 . 2 5}(5.85)$ & $\mathrm{H}_{1}$ & Accepted \\
Procedural Justice & $\mathbf{0 . 5 4}(11.78)$ & $\mathrm{H}_{2}$ & Accepted \\
Interactional Justice & $\mathbf{0 . 7 0}(14.03)$ & $\mathrm{H}_{3}$ & Accepted \\
Distributive Justice & $\mathbf{R}^{\mathbf{2}=\mathbf{0 . 8 5}}$ & & \\
& $\mathbf{0 . 6 7}(13.59)$ & $\mathrm{H}_{4 \mathrm{~A}}$ & Accepted \\
Dependent Variable: Consumer Trust in the Firm Website & $\mathrm{H}_{5}$ & Not Accepted \\
Satisfaction with Complaint Handling & $\mathbf{0 . 0 6}(1.38)$ & $\mathrm{H}_{9}$ & Accepted \\
Consumer Trust in Online Retailing & $\mathbf{0 . 3 5}(25.07)$ & $\mathrm{H}_{8}$ & Accepted \\
Familiarity with the Company's Web Site & $\mathbf{0 . 1 5}(4.09)$ & & \\
Prior Experience with the Company's Web Si & $\mathbf{R}^{2}=\mathbf{0 . 6 1}$ & & Contings \\
\hline
\end{tabular}

Continues 
Table 1 (continued)

\begin{tabular}{|c|c|c|c|}
\hline Model Relationships & $\begin{array}{l}\text { Standardized Regression } \\
\text { Coefficient }\end{array}$ & Hypotheses & Findings \\
\hline \multicolumn{4}{|c|}{ Dependent Variable: Consumer Trust in Online Retailing } \\
\hline Satisfaction with Complaint Handling & $0.14(3.27)$ & $\mathrm{H}_{4 \mathrm{~B}}$ & Accepted \\
\hline Consumer Trust in the Company's Web Site & $0.02(1.08)$ & $\mathrm{H}_{5}$ & Not Accepted \\
\hline Familiarity with the Internet & $0.25(5.25)$ & $\mathrm{H}_{7}$ & Accepted \\
\hline \multirow[t]{2}{*}{ Prior Experience with online purchasing } & $0.36(7.26)$ & $\mathrm{H}_{6}$ & Accepted \\
\hline & $\mathbf{R}^{2}=\mathbf{0 . 2 1}$ & & \\
\hline \multicolumn{4}{|c|}{ Dependent Variable: Repurchase Intention from the Site } \\
\hline Consumer Trust in the Company's Web Site & $\mathbf{0 . 8 7}(16.15)$ & $\mathrm{H}_{10 \mathrm{~A}}$ & Accepted \\
\hline \multirow[t]{2}{*}{ Perceived Value } & $\mathbf{0 . 0 3}(0.89)$ & $\mathrm{H}_{12 \mathrm{~A}}$ & Not Accepted \\
\hline & $\mathbf{R}^{2}=0.76$ & & \\
\hline \multicolumn{4}{|c|}{ Dependent Variable: Positive Word-Of-Mouth about the Site } \\
\hline Consumer Trust in the Company's Web Site & $0.86(15.68)$ & $\mathrm{H}_{10 \mathrm{~B}}$ & Accepted \\
\hline \multirow[t]{2}{*}{ Perceived Value } & $0.01(0.34)$ & $\mathrm{H}_{12 \mathrm{~B}}$ & Not Accepted \\
\hline & $\mathbf{R}^{2}=\mathbf{0 . 7 4}$ & & \\
\hline \multicolumn{4}{|c|}{ Dependent Variable: Positive Word-Of-Mouth about Online Shopping } \\
\hline \multirow[t]{2}{*}{ Consumer Trust in Online Retailing } & $\mathbf{0 . 6 1}(13.09)$ & $\mathrm{H}_{11 \mathrm{~B}}$ & Accepted \\
\hline & $\mathbf{R}^{2}=\mathbf{0 . 3 8}$ & & \\
\hline \multicolumn{4}{|l|}{ Goodness-of-fit Indices: } \\
\hline$\chi 2$ (Chi-square) & $24276,096(\mathrm{p}<0.001)$ & $\begin{array}{l}\text { DF (Degrees of } \\
\text { Freedom) }\end{array}$ & 1309 \\
\hline CFI (Comparative Fit Index) & 0.96 & $\begin{array}{l}\text { NNFI (NonNorme } \\
\text { Fit Index) }\end{array}$ & 0.96 \\
\hline NFI (Normed Fit Index) & 0.96 & $\begin{array}{l}\text { RMR (Root Mean } \\
\text { Sq. Residual) }\end{array}$ & 0.32 \\
\hline RMSEA (Root Mean Sq. Error of Approx.) & 0.06 & & \\
\hline
\end{tabular}

Note. ${ }^{a}$ t-values between parentheses. Based on the two-tail test: $t$-values $>1.65=p<0.05$; and $t$-values $>2.33=p<0.01$. Significant coefficients are in bold (all at level 0.01).

Regarding consumer trust in online purchasing, familiarity and prior experience with the Internet exert a higher effect than satisfaction with complaint handling. These three variables could explain $21 \%$ of variance in consumer online trust. Moreover, the reciprocal effect of the dimensions of trust was not confirmed since the effects of trust in the firm's web site on trust in Internet shopping and vice-versa were not statistically significant $(0.02, \mathrm{t}=1.08$ and $0.06, \mathrm{t}=1.38$, respectively). The impact of trust on consumer repurchase intention from the same web site, supposed in $\mathrm{H}_{10 \mathrm{~A}}$, was confirmed. Nonetheless, whereas the level of consumer trust had a significant effect on consumer repurchase intention (regression coefficient of 0.87 ), the relationship between value and repurchase intention was null (coefficient of 0.03 ), thereby rejecting the $\mathrm{H}_{12 \mathrm{~A}}$. Concerning word-of-mouth communication about the firm's web site, similar effects were encountered, that is, trust exerted a major impact and perceived value did not present a significant coefficient estimate, thus rejecting hypothesis $\mathrm{H}_{12 \mathrm{~B}}$. In the dimension of word-of-mouth about the website, the proportion of variation explained by trust in the firm's website (0.74) supports the importance of trust in the consumer's 
intention to recommend a firm's web site and in the development of an ongoing relationship between the consumer and the firm.

Finally, the impact of trust in online purchasing on repurchase intention from the Internet as a whole and on word-of-mouth about online purchasing, predicted by $\mathrm{H}_{12 \mathrm{~A}}$ and $\mathrm{H}_{12 \mathrm{~B}}$, posits trust as an important antecedent of the customer's actions toward the Internet in the future. Moreover, the $\mathrm{R}^{2}$ estimates also reveal that, besides the great effect of trust, other predictors may be employed to improve the proportion of variance explained.

\section{Conclusions and Implications}

This article aimed to provide and test a theory-based framework for mapping the mechanisms underlying the recovery process in relation to online exchanges. This study offers three distinct contributions. First, we conceptualize consumer trust as a bi-dimensional construct to obtain a finegrained understanding of its differential effects. This conceptualization is sustained by the recognition of the multidimensionality of trust in the interorganizational and marketing literature. Second, it proposes a model with interrelationships among web site-specific recovery evaluations and attitudes toward online purchasing as a whole (e.g., intention to repurchase online and positive word-of-mouth about Internet shopping). This provides valuable insights that can be applied in the formulation of a dynamic portrayal of online purchasing. Third, our results support the view that concepts of justice, in the online context, provide an effective theoretical framework for explaining satisfaction with complaint situations, which in turn is closely linked to both trust and loyalty, offering empirical support for the proposition that complaint handling is closely tied to relationship marketing. Each contribution provides new insights into the recovery process involving consumers and virtual providers.

While the bi-dimensionality of trust is ultimately an empirical (rather than merely a psychometric) matter, systematic studies establishing the validity and usefulness of trust dimensions have been lacking in the literature (Singh \& Sirdeshmukh, 2000). We established that (a) consumer trust involves two distinct facets: one relating to the web site and the other concerning Internet purchasing as a whole; (b) these trust dimensions influence its respective dimension of loyalty (e.g., trust in the company's web site influences repurchase intention from the site but not from the Internet as a whole); and (c) they should influence each other. While these dimensions of consumer online trust have been supported in previous research (Chen \& Dhillon, 2003; Grabner-Krauter \& Kaluska, 2003; Lee \& Turban, 2001; McKnight, Choudhury, \& Kacmar, 2002; Milne \& Boza, 1999), their interrelationships have not been proposed and tested heretofore. However, in contrast with the confirmatory results related to the two first propositions, we found that trust in the company's site does not influence trust in Internet purchasing or vice-versa. This suggests the existence of distinct nodes on which each dimension of consumer trust is formed.

Moreover, the results reveal not only the absence of any association between trust in the web site and in the Internet medium, but also that constructs related particularly to the web merchant (e.g., satisfaction with complaint handling and trust in the company's web site) do not impact on more 'general' variables such as trust and loyalty to the online environment. This lack of influence sheds some light on the existence of other mechanisms and variables, such as the consumer's overall satisfaction with his/her previous online purchases (not measured in this study). These results indicate that recovery efforts are essential for building and maintaining strong and long-lasting relationships with the company's web site, but do not influence the customer's view of Internet shopping as a whole. One explanation for this is that we dealt with experienced consumers since a large part of our sample is composed of consumers who had already acquired considerable experience of shopping on the Internet. These consumers know exactly how the Internet works and are less inclined to change attitudes due to a single experience. 
Analyzing the links between the dimensions of trust and the dimensions of loyalty, consumer trust emerged as the strongest antecedent of repurchase and recommendation intentions. This result is in accordance with the logic that with the increase in consumer trust they begin to believe that the company will continue to act consistently and competently in the future, thus reducing the risks associated to service purchase and creating the belief that consumers will continue to obtain value in further dealings with the provider. In other words, the greater the trust of the consumer the higher the probability of engaging in future exchanges with this company and maintaining a long-term relationship. However, it should not be forgotten that satisfaction with the complaint process has an indirect effect on loyalty, through its impact on consumer trust in the firm's web site. Hence, it can be inferred that complaint management plays a central role in building long-lasting relationships between a company and consumers. The inappropriate handling of a complaint would generate a "double deviation", that is, the company fails twice to meet the customer's needs. Consequently, consumer trust is reduced and, in some cases, destroyed, leading the customer to try a competing company.

Another point to emphasize is the impact of the interactional dimension of justice on satisfaction with complaint handling. Past research into the service encounter and Fairness Theory (Folger \& Cropanzano, 1998) suggests that considerations of interactional justice are crucial in service recovery situations. In the online environment, interactional aspects were expected to be a weak or non-existent factor in satisfaction with complaint handling because there is little opportunity for service employees to be in contact with consumers. Contrary to this, the findings show that in online purchase recoveries poor personal treatment violates basic human needs such as fairness and a sense of self-worth and may result in customer defection and greater intention to spread bad word-of-mouth. Therefore, the present study advocates the role of interpersonal treatment in customer-web merchant interactions in online recovery situations.

The significant impacts of prior experiences and familiarity on trust lead to the idea that investigating the impact of the complaints in the virtual context without including aspects related to the 'history' of the consumer with this context (i.e., prior experiences, familiarity and perceived value) would mean omitting important causal variables and ignoring the dynamic that guides marketing exchanges. Furthermore, it was expected that online consumers would value aspects such as time, convenience and effort in future exchanges with the same provider, but we found a very weak impact of value on loyalty to the web site. Although it seems surprising, the literature has shown contradictory results, that is, some studies reporting a strong effect of value on loyalty (e.g., Broekhuizen, 2006; Harris \& Goode, 2004), and others indicating a non-significant effect (e.g., Warrington, Abgrab, \& Caldwell, 2000). One explanation for this is that consumers can easily make comparisons online and do not distinguish the attractiveness of alternative suppliers. As the Internet provides convenience and information almost instantaneously, consumers would not construct a distinguished value for a particular web merchant.

From the managerial point of view, some contributions can be offered. Overall, the results demonstrate that complaints are more than a chance for the company to review and improve its processes; they are opportunities to create solid relationships with customers. In this line, the findings support the idea that e-retailers should provide consumers with the opportunity to speak directly with a representative during and after a purchase, as many sites have done, because it might improve the perceptions of interpersonal justice which, in turn, enhances satisfaction with complaint handling, trust and loyalty.

Moreover, our descriptive data showed that consumers' perceptions of fairness are quite tepid and strongly indicate that online selling channels have ample opportunity for improvement in this area. We believe e-tailers should look for a deeper understanding of how to design online retailer sites that convey a commitment to procedural, distributive and interactional fairness and employ effective recovery mechanisms. Online companies may become even more dependent on their service staff's ability to interpret the specifics of each service failure and, during recovery, to take into consideration the specific needs and experiences of the consumer when formulating an approach to their resolution. Specific training in the light of these findings should be designed to ensure that customer service 
representatives implement the most appropriate recovery actions based on the unique characteristics of each complaint.

The proposed model is an initial attempt toward modeling complaint handling in the online environment phenomenon, despite the fact we surveyed about 3,000 people. We do not view our model as a completely novel approach for understanding failure-recovery process related to online exchanges. Rather, our model brings together different perspectives and streams of work that are well grounded, and we hope that it will serve to motivate interest in the topic and encourage future researchers to refine and enhance the proposed framework.

Contributions brought by this study should be considered while bearing in mind its limitations. This paper used a cross-sectional approach, based on a non-probabilistic sample, composed of people who were online when data collection occurred. Furthermore, our sample has indicated a high level of online purchasing and strong familiarity with the Internet and with the site in question. In this perspective, the generalization of results is limited. Additionally, our study explored B2C transactions and may not be easily generalized to other types of transactions (e.g., business-to-business and customer-to-customer).

Future research focusing on the interactions between the dimensions of justice and its impact directly on consumer trust will promote a better understanding of the service recovery phenomenon. We also encourage other researchers to study the role of switching costs and its direct effect on loyalty and as a moderator in the proposed framework. Following the idea of Garbarino and Johnson (1999), future research could try to understand how the type of connection between clients and online companies can influence complainers' evaluations of the recovery process and its consequences. This is a critical piece of information for online organizations, as they may be able to adapt their service recovery strategies to better accommodate these different relationships. Moreover, the moderating role of the online purchase experience in the framework could be explored, based on Holloway et al. (2005).

Finally, while failures in the traditional retail context are often attributable to employee behavior (Bitner et al., 1990; Kelley, Hoffman, \& Davis, 1993), failures in online retailing are most commonly due to system design flaws, delivery delays or problematic products (Forbes et al., 2005; Holloway \& Beatty, 2003). Yet, in both online and offline contexts, few empirical studies have examined the differential effects of the various failure types on the complaint handling framework.

\section{Received 23 June 2009; received in revised form 30 August 2010.}

\section{References}

Anderson, J. C., \& Grebing, D. W. (1988). An updated paradigm for scale development incorporating unidimensionality and its assessment. Journal of Marketing Research, 25(2), 186-192. doi: $10.2307 / 3172650$

Agustin, C., \& Singh, J. (2005). Curvilinear effects of consumer loyalty determinants in relational exchanges. Journal of Marketing Research, 42(1), 96-108. doi: 10.1509/jmkr.42.1.96.56961

Ahmad, S. (2002). Service failures and customer defection: a closer look at online shopping experiences. Managing Service Quality, 12(1), 19-30. doi: 10.1108/09604520210415362

Alba, J., Hutchinson, W., \& Wesley, J. (1987). Dimensions of consumer expertise. Journal of Consumer Research, 13(4), 411-455. doi: 10.2307/2489367

Berry, L., \& Parasuraman, A. (1991). Marketing services: competing through quality. New York, NY: The Free Press. 
Bettman, J. R., \& Park, C. W. (1980). Effects of prior knowledge and experience and phase of the choice process on consumer decision processes: a protocol analysis. Journal of Consumer Research, 7(3), 234-248.

Bitner, M. J., Booms, B. H., \& Tetreault, M. (1990). The service encounter: diagnosing favorable and unfavorable incidents. Journal of Marketing, 54(1), 71-84.

Blodgett, J. G., Hill, D. J., \& Tax, S. S. (1997). The effects of distributive, procedural, and interactional justice on postcomplaint behavior. Journal of Retailing, 73(2), 185-210. doi: 10.1016/S0022-4359(97)90003-8

Broekhuizen, T. (2006). Understanding channel purchase intentions: measuring online and offline shopping value perception (Unpublished doctoral thesis). Groningen University, Groningen, Netherlands.

Byrne, B. M. (1994). Structural equation modeling with EQS and EQS/Windows. Thousand Oaks, CA: Sage Publications.

Chen, S., \& Dhillon, G. (2003). Interpreting dimensions of consumer trust in e-commerce. Information Technology and Management, 4(2), 303-318. doi: 10.1023/A:1022962631249

Chiou, J. (2004). The antecedents of consumers' loyalty toward internet service providers. Information \& Management, 41(6), 685-695. doi. 10.1016/j.im.2003.08.006

Clemmer, E. C. (1988). The role of fairness in customer satisfaction with services (Unpublished doctoral dissertation). University of Maryland, Maryland, USA.

Dube, L., \& Maute, M. F. (1998). Defensive strategies for managing satisfaction and loyalty in the service industry. Psychology \& Marketing, 15(8), 775-791. doi: 10.1002/(SICI)15206793(199812)15:8<775::AID-MAR4>3.0.CO;2-\#

Folger, R., \& Cropanzano, R. (1998). Organizational justice and human resource management. London: Sage Publications.

Forbes, L., Kelley, S., \& Hoffman, D. (2005). Typologies of e-commerce retail failures and recovery strategies. Journal of Services Marketing, 19(5), 280-292. doi: 10.1108/08876040510609907

Fornell, C., \& Larcker, D. F. (1981). Evaluating structural equation models with unobservable variables and measurement error. Journal of Marketing Research, 18(1), 39-50. doi: $10.2307 / 3151312$

Garbarino, E., \& Johnson, M. (1999). The roles of satisfaction, trust and commitment for relational and transactional consumers. Journal of Marketing, 63(2), 70-87.

Gefen, D. (2000). E-commerce: the role of familiarity and trust. Omega, 28(6), 725-737. doi: 10.1016/S0305-0483(00)00021-9

Goodwin, C., \& Ross, I. (1992). Consumer responses to service failures: influence of procedural and interactional fairness perceptions. Journal of Business Research, 25(2), 149-163. doi: 10.1016/0148-2963(92)90014-3

Grabner-Krauter, S., \& Kaluska, E. (2003). Empirical research in online trust: review and assessment. International Journal of Human-Computer Studies, 58(6), 783-812. doi: 10.1016/S10715819(03)00043-0

Hair, J., Anderson, R., Tatham, R., \& Black, W. (1998). Multivariate data analysis. New Jersey: Prentice Hall. 
Harris, L. C., \& Goode, M. H. (2004). The four levels of loyalty and the pivotal role of trust: a study of online service dynamics. Journal of Retailing, 80(2), 139-158. doi: 10.1016/j.jretai.2004.04.002

Holloway, B., \& Beatty, S. E. (2003). Service failure in online retailing - a recovery opportunity. Journal of Service Research, 6(1), 92-105. doi: 10.1177/1094670503254288

Holloway, B., Wang, S., \& Parish, J. (2005). The role of online purchasing experience in service recovery management. Journal of Interactive Marketing, 19(3), 54-67.

Jarvenpaa, S., Tractinsky, N., \& Vitale, M. (2003). Consumer trust in an internet store. Information Technology and Management, 1(1-2), 45-71. doi: 10.1023/A:1019104520776

Kelley, S. W., Hoffman, K. D., \& Davis, M. A. (1993). A typology of retail failures and recoveries. Journal of Retailing, 69(4), 429-452. doi: 10.1016/0022-4359(93)90016-C

Kumar, N. (1996). The power of trust in manufacturer-retailer relationships. Harvard Business Review, 74(6), 92-106.

Lee, M. K. O., \& Turban, E. (2001). A trust model for consumer internet shopping. International Journal of Electronic Commerce, 6(1), 75-91.

Liao, H. (2007). Do it right this time: the role of employee recovery in customer-perceived justice and loyalty after service failures. Journal of Applied Psychology, 92(2), 475-489. doi: 10.1037/0021-9010.92.2.475

Lohse, G. L., Bellman, S., \& Johnson, E. (2000). Consumer buying behavior on the internet: findings from panel data. Journal of Interactive Marketing, 14(1), 15-29. doi: 10.1002/(SICI)15206653(200024)14:1<15::AID-DIR2>3.0.CO;2-C

Mattila, A., \& Patterson, P. (2004). Service recovery and fairness perceptions in collectivist and individualist contexts. Journal of Service Research, 6(4), 336-346. doi: $10.1177 / 1094670503262947$

Mayer, R. C., Davis, J. H., \& Schoorman, F. D. (1995). An integrative model of organizational trust. Academy of Management Review, 29(3), 709-734. doi: 10.2307/258792

McKnight, D. H., Choudhury, V., \& Kacmar, C. (2002). Developing and validating trust measures for e-commerce: an integrative typology. Information Systems Research, 13(3), 334-359. doi: 10.1287/isre.13.3.334.81

Messick, D., \& Cook, K. (1983) Equity theory: psycho and socio perspectives. New York: Praeger.

Milne, G. R., \& Boza, M. E. (1999). Trust and concern in consumer's perceptions of marketing information management practices. Journal of Interactive Marketing, 13(1), 5-24. doi: 10.1002/(SICI)1520-6653(199924)13:1<5::AID-DIR2>3.0.CO;2-9

Moreau, C., Lehmann, D., \& Markman, A. (2001). Entrenched knowledge structures and consumer response to new products. Journal of Marketing Research, 38(1), 14-30. doi: $10.1509 / \mathrm{jmkr} .38 .1 .14 .18836$

Morgan, R. M., \& Hunt, S. D. (1994). The commitment-trust theory of relationship marketing. Journal of Marketing, 58(3), 20-38.

Nasir, A. (2004). E-consumer complaints about online stores. Journal of Consumer Satisfaction, Dissatisfaction and Complaining Behavior, 17, 68-88. 
Nijssen, E., Singh, J., Sirdeshmukh, D., \& Holzmueller, H. (2003). Investigating industry context effects in consumer-firm relationships: preliminary results from a dispositional approach. Journal of the Academy of Marketing Science, 31(1), 46-60. doi: 10.1177/0092070302238604

Nooteboom, B., Berger, H., \& Noorderhaven, N. G. (1997). Effects of trust and governance relational risk. Academy of Management Journal, 40(2), 308-338.

Oliver, R. L., \& Swan, J. (1989). Consumer perceptions of interpersonal equity and satisfaction in transactions: a field survey approach. Journal of Marketing, 53(2), 21-35. doi: 10.2307/1251411

Pavlou, P. A. (2003). Consumer acceptance of electronic commerce: integrating trust and risk with the technology acceptance model. International Journal of Electronic Commerce, 7(3), 101-134.

Reichheld, F. F., \& Schefter P. (2000). E-loyalty. Your secret weapon on the web. Harvard Business Review, 78(4), 105-113.

Ribbink, D., Van Riel, A., Liljander, V., \& Streukens, S. (2004). Comfort your online customer: quality, trust and loyalty on internet. Managing Service Quality, 14(6), 446-456. doi: $10.1108 / 09604520410569784$

Santos, C. P., \& Rossi, C. A. V. (2002, May). The impact of complaint handling on consumer's trust and loyalty in the context of relational services exchanges. Proceedings of the European Marketing Academy Conference, Braga, Portugal, 31.

Shankar, V., Smith, A., \& Rangaswamy, A. (2003). Customer satisfaction and loyalty in online and offline environments. International Journal of Research in Marketing, 20(2), 153-175. doi: $10.1016 / \mathrm{S} 0167-8116(03) 00016-8$

Singh, J., \& Sirdeshmukh, D. (2000). Agency and trust mechanisms in consumer satisfaction and loyalty judgements. Academy of Marketing Science Journal, 28(1), 150-168. doi: 10.1177/0092070300281014

Sirdeshmukh, D., Singh, S., \& Sabol, B. (2002). Consumer trust, value and loyalty in relational exchanges. Journal of Marketing, 66(1), 15-37. doi: 10.1509/jmkg.66.1.15.18449

Smith, A., \& Bolton, R. (1998). An investigation of customer reactions to service failure and recovery encounters: paradox or peril? Journal of Service Research, 1(1) 65-81. doi: $10.1177 / 109467059800100106$

Smith, A., Bolton, R., \& Wagner, J. (1999). A model of customer satisfaction with service encounter failure and recovery. Journal of Marketing Research, 36(3), 356-372.

Suk, K., \& Mitchell, A. (2004). The effect of usage situation familiarity on memory, brand retrieval, and consideration (Unpublished report/2004), Toronto, ON, Canada, University of Toronto.

Sultan, F., Urban, G., Shankar, V., \& Bart, I. (2002). Determinants and role of trust in e-business: a large-scale empirical study [Working Paper $\mathrm{N}^{\mathrm{o}}$ 4282-02]. MIT Sloan School of Management, Cambridge, MA, USA.

Tax, S., Brown, S., \& Chandrashekaran, M. (1998). Customer evaluations of service complaint experiences: implications for relationship marketing. Journal of Marketing, 62(2), 60-76.

Thibaut, J., \& Walker, L. (1975). Procedural justice: a psychological analysis. Hillsdale, NJ: Lawrence Erlbaum.

Warrington, T., Abgrab, N., \& Caldwell, H. (2000). Building trust to develop competitive advantage in e-business relationships. Competitiveness Review, 10(2), 160-170. doi: 10.1108/eb046409 
Webster, C., \& Sundaram, D. S. (1998). Service consumption criticality in failure recovery. Journal of Business Research, 41(2), 153-159. doi: 10.1016/S0148-2963(97)00004-0

Westbrook, R. A. (1987). Product/consumption-based affective responses and postpurchase processes. Journal of Marketing Research, 24(3), 258-270. doi: 10.2307/3151636

Weun, S., Beauty, S., \& Jones, M. (2004). The impact of service failure severity on service recovery evaluations and post-recovery relationships. The Journal of Services Marketing, 18(2), 133-146. doi: $10.1108 / 08876040410528737$

Yoh, E., Damhorst, M. L., Sapp, S., \& Laczniak, R. N. (2003). Consumer adoption of the internet: the case of apparel shopping. Psychology \& Marketing, 20(12), 1095-1118. doi: 10.1002/mar.10110

Yoon, S. (2002). The antecedents and consequences of trust in online-purchase decisions. Journal of Interactive Marketing, 16(2), 47-63. doi: 10.1002/dir.10008

Zeithaml, V. A., Berry, L. L., \& Parasuraman, A. (1996). The behavioral consequences of service quality. Journal of Marketing, 60(2), 31-46. doi: 10.2307/1251929

Zemke, R., \& Connellan, T. (2001). Online customers. Executive Excellence, 18(8), 3-6. 


\section{APPENDIX}

\section{Operational measures used for study constructs}

Familiarity with Internet Purchases ${ }^{(\mathbf{1})}$
1. What is your expertise with purchases on the Internet?
2. I am familiar with buying on the Internet.
3. I am familiar with searching for products on the Internet.
Prior Experiences with Internet Purchases ${ }^{1}$
1. My past experience in Internet purchases in general was positive.
2. E-vendors, on average, did a good job in experiences I had with
them in the past.
3. I received excellent service from e-vendors in general in the past.

\section{Familiarity with the Website ${ }^{(1)}$}

1. What is your level of experience with purchases through this website?

\begin{tabular}{cc}
$\begin{array}{c}\text { Coefficient } \\
\text { Alpha }\end{array}$ & $\begin{array}{c}\text { Factor } \\
\text { Loadings }\end{array}$ \\
\hline 0.84 & \\
& 0.76 \\
& 0.71 \\
& 0.78
\end{tabular}

0.93

0.78

$4.28(0.82)$

0.78

0.82

2. I am familiar with buying on this website.

3. I am familiar with searching for products on this website.

0.84

Prior Experiences with the Website ${ }^{(1)}$

0.97

0.73

$3.81(1.09)$

1. My past experience on this website was positive.

2. This website did a good job in experiences I had with it in the past.

3. I received excellent service from this website in the past.

Interpersonal Fairness $^{(1)}$

1. They communicated honestly with me.

0,93

0.72

0.75

2. The people were courteous to me.

0.73

0.92

3. I was given a reasonable explanation as to why the original problem occurred.

0.92

4. They seemed very concerned about my problem.

5. They tried hard to resolve the problem.

6. The people apologized for the problem.

\subsection{7}

\section{Procedural Fairness ${ }^{(1)}$}

1. I got a chance to tell them the details of my problem.

0.62

0.71

2. I had some control over the result I received from the complaint.

4. They adapted their complaint handling procedures to satisfy my needs.

5. They made it easy for me to voice my complaint.

0.66

6. They assumed the responsibility for the problem.

0.65

Distributive Fairness $^{(1)}$

0,95

0.86

$3.03(1.56)$ 


\section{(Continued)}

\begin{tabular}{|c|c|c|c|c|}
\hline & $\begin{array}{l}\text { Coefficient } \\
\text { Alpha }\end{array}$ & $\begin{array}{l}\text { Factor } \\
\text { Loadings }\end{array}$ & $\begin{array}{l}\text { Composite } \\
\text { Reliability }\end{array}$ & $\begin{array}{l}\text { Mean } \\
(\mathrm{SD})\end{array}$ \\
\hline Procedural Fairness $^{(1)}$ & 0,87 & & 0.85 & $2.95(1.16)$ \\
\hline 1. I got a chance to tell them the details of my problem. & & 0.62 & & \\
\hline 2. I had some control over the result I received from the complaint. & & 0.71 & & \\
\hline 3. They responded quickly to my complaint. & & 0.83 & & \\
\hline $\begin{array}{l}\text { 4. They adapted their complaint handling procedures to satisfy my } \\
\text { needs. }\end{array}$ & & 0.83 & & \\
\hline 5. They made it easy for me to voice my complaint. & & 0.66 & & \\
\hline 6. They assumed the responsibility for the problem. & & 0.65 & & \\
\hline Distributive Fairness $^{(1)}$ & 0,95 & & 0.86 & $3.03(1.56)$ \\
\hline 1. The result of the complaint was fair. & & 0.93 & & \\
\hline 2. In resolving the complaint, the company gave me what I needed. & & 0.90 & & \\
\hline 3. The result of the complaint was what I expected. & & 0.91 & & \\
\hline Satisfaction with Service Recovery ${ }^{(1)}$ & 0,97 & & 0.89 & $2.79(1.53)$ \\
\hline 1. I was happy with how the organization handled my complaint. & & 0.92 & & \\
\hline $\begin{array}{l}\text { 2. I was pleased with the manner in which the complaint was dealt } \\
\text { with. }\end{array}$ & & 0.95 & & \\
\hline $\begin{array}{l}\text { 3. Overall I was not satisfied with the way the complaint was } \\
\text { handled. }\end{array}$ & & 0.97 & & \\
\hline Consumer Trust in the Firm's Website & 0,94 & & 0.81 & $3.11(1.32)$ \\
\hline \multicolumn{5}{|l|}{ I feel that the this company's site is: } \\
\hline 1. Very Undependable/Very Dependable & & 0.73 & & \\
\hline 2. Very Incompetent/Very Competent & & 0.86 & & \\
\hline 3. Of Very Low Integrity/Of Very High Integrity & & 0.79 & & \\
\hline 4. Very Unresponsive to Customers/Very Responsive to Customers & & 0.83 & & \\
\hline Consumer Trust in Online Retailing & 0,91 & & 0.82 & $3.79(0.86)$ \\
\hline \multicolumn{5}{|l|}{ I feel that Online retailing is: } \\
\hline 1. Very Undependable/Very Dependable & & 0.83 & & \\
\hline 2. Very Incompetent/Very Competent & & 0.87 & & \\
\hline 3. Of Very Low Integrity/Of Very High Integrity & & 0.86 & & \\
\hline 4. Very Unresponsive to Customers/Very Responsive to Customers & & 0.69 & & \\
\hline Perceived Value & 0,83 & & 0.75 & $3.73(0.92)$ \\
\hline \multicolumn{5}{|l|}{$\begin{array}{l}\text { Please tell us your evaluation of the web merchant on the following } \\
\text { factors: }\end{array}$} \\
\hline $\begin{array}{l}\text { 1. The prices you pay for purchases on this site are: Very Poor } \\
\text { Deal/Very Good Deal }\end{array}$ & & 0.71 & & \\
\hline $\begin{array}{l}\text { 2. The time you spent in order to purchase on this site is: Highly } \\
\text { Unreasonable/Highly Reasonable }\end{array}$ & & 0.89 & & \\
\hline $\begin{array}{l}\text { 3. The effort involved in dealing with this site is: Not At All } \\
\text { Worthwhile/Very Worthwhile }\end{array}$ & & 0.83 & & \\
\hline
\end{tabular}




\section{(Continued)}

\begin{tabular}{|c|c|c|c|c|}
\hline & $\begin{array}{l}\text { Coefficient } \\
\text { Alpha }\end{array}$ & $\begin{array}{l}\text { Factor } \\
\text { Loadings }\end{array}$ & $\begin{array}{l}\text { Composite } \\
\text { Reliability }\end{array}$ & $\begin{array}{l}\text { Mean } \\
(\mathrm{SD})\end{array}$ \\
\hline Website Loyalty - Word-of-mouth ${ }^{(2)}$ & 0,98 & & 0.90 & $2.82(1.57)$ \\
\hline \multicolumn{5}{|l|}{ How likely are you to: } \\
\hline 1. Recommend this site to friends, neighbors and relatives? & & 0.90 & & \\
\hline 3. Say positive things about this site to other people? & & 0.97 & & \\
\hline 5. Encourage your friends and family to do business with this site? & & 0.97 & & \\
\hline Website Loyalty - Retention ${ }^{(2)}$ & 0,95 & & 0.87 & $2.89(1.52)$ \\
\hline 2. Make purchases on this site again? & & 0.95 & & \\
\hline 4. Do more business with this site in the future? & & 0.95 & & \\
\hline $\begin{array}{l}\text { 6. Consider this site as your first choice to buy that kind of } \\
\text { service/product? }\end{array}$ & & 0.86 & & \\
\hline Internet Channel Loyalty - Word-of-mouth ${ }^{2}$ & 0,96 & & 0.89 & $4.36(0.94)$ \\
\hline \multicolumn{5}{|l|}{ How likely are you to: } \\
\hline $\begin{array}{l}\text { 1. Recommend the Internet as a purchase channel to friends, } \\
\text { neighbors and relatives? }\end{array}$ & & 0.91 & & \\
\hline 3. Say positive things about online retailing to other people? & & 0.97 & & \\
\hline 5. Encourage your friends and family to do business online? & & 0.94 & & \\
\hline Internet Channel Loyalty - Retention ${ }^{(2)}$ & 0,87 & & 0.77 & $4.43(0.84)$ \\
\hline 2. Make purchases on the Internet again? & & 0.89 & & \\
\hline 4. Do more business on the Internet in the future? & & 0.90 & & \\
\hline $\begin{array}{l}\text { 6. Consider the Internet Channel as your first choice to buy that } \\
\text { kind of service/product? }\end{array}$ & & 0.61 & & \\
\hline
\end{tabular}

Note. ${ }^{1}$ Anchored by Strongly Disagree / Strongly Agree; ${ }^{2}$ Anchored by Very unlikely / Very likely. 